\title{
Sustainable building materials using textile effluent treatment plant sludge: a review
}

Udaysingh Patil MTech

Research Scholar and Assistant Professor, Department of Civil Engineering, Yeshwantrao Chavan College of Engineering, Nagpur, India

Sanjay Padmakar Raut PhD

Associate Professor, Department of Civil Engineering, Yeshwantrao Chavan College of Engineering, Nagpur, India
Rahul V. Ralegaonkar PhD

Professor, Department of Civil Engineering, Visvesvaraya National Institute of Technology, Nagpur, India

Mangesh V. Madurwar PhD

Assistant Professor, Department of Civil Engineering, Visvesvaraya National Institute of Technology, Nagpur, India (corresponding author: mangesh_bits@yahoo.com)

\begin{abstract}
A huge quantity of textile effluent sludge is generated from 21076 textile units of India and dumped in large areas, leading to contamination of soil, surface water and groundwater. Hence, effective management of this sludge is important for its reuse and safe disposal. Considering the utilization of this waste in construction activities, the current paper explores the potential of textile sludge produced from textile industry effluent treatment plants. Many researchers have attempted to reuse this sludge for the development of sustainable construction materials and suggested its optimum usage as a partial substitution for fine aggregate, cement and clay with or without additives for the manufacturing of non-structural building components. This paper provides a critical review of the production of non-structural elements - namely, sustainable building blocks, clay bricks, mortar and paver blocks - using textile effluent treatment plant sludge and recommends optimum ranges of 5-30, 5-40, 5-50 and 20-40\%, respectively. The prominent gaps are suggested as the outcome of studies such as techno-economic feasibility of the product, thermal and energy building simulation along with the life-cycle assessment and fatigue life assessment of the developed paver blocks.
\end{abstract}

\section{Introduction}

Due to rapid industrialization in developing countries and subsequent increase in human activities, there is a continuous accumulation of industrial wastes, which are becoming increasingly difficult to manage day by day. A great area is utilized in dumping these industrial wastes, which may lead to contamination of soil, surface water and groundwater. ${ }^{1}$ Hence, recycling these wastes into an innovative material could be a practical solution to the problem of landfilling and reduce its impact on the environment. Also, urbanization in urban/ rural areas has increased the demand for construction materials, and thus, the demand for new construction materials that are economically feasible is increasing exponentially. According to a report, there will be a galloping demand for construction materials to alleviate the housing shortage. ${ }^{2}$ As per the report of the Ministry of Urban Housing and Poverty Alleviation (technical group) of an estimation of the urban housing shortage ${ }^{3}$ and the report of the working group on the rural housing shortage, ${ }^{4}$ in 2012 , India's total urban housing shortage was 18.78 million, while the rural housing shortage was projected to be 43.9 million (Figure 1(a)). ${ }^{3,4}$ It is worth noting that $90 \%$ of this shortage pertains to the socially deprived and the lowerincome classes of the society. This massive number is a cause for concern. One of the reasons behind it is the high cost of building materials. Thus, an economically weaker sector cannot afford the high construction cost. To meet these demands, there is a need for an increase in the production of materials, which leads to another issue namely, carbon dioxide $\left(\mathrm{CO}_{2}\right)$ emissions. Figure 1(b) shows that the production of steel, cement, bricks and lime has increased from 2000 to 2020. Hence, increases in the consumption of energy and carbon dioxide emissions can therefore be seen (Figures 1(c) and 1(d)). ${ }^{2}$ In India, the construction sector emits around $22 \%$ of the total emission of carbon dioxide annually, out of which $80 \%$ results mainly from the industrial processes involved in the production of steel, cement, bricks and lime. Therefore, there is a need to develop sustainable, economically viable and modular construction materials to meet the ever-increasing demand for construction materials without exploiting the available natural resources. This will help reduce carbon dioxide emissions and provide an alternative solution for solid waste management. Many researchers have incorporated various wastes to develop sustainable construction materials, such as ladle furnace slag, blast slag, iron $(\mathrm{Fe})$ tailings, zinc $(\mathrm{Zn})$ tailings and several sewage sludges. Such wastes can end up being a sustainable solution to disposal and environmental issues.

India is the world's second largest manufacturer and exporter, with a huge raw material base and strength. India accounts for 5\% of the world's clothing and apparel trade. The textile industry accounts for $2 \%$ of the gross domestic product and $15 \%$ of the nation's export earnings. ${ }^{5}$ About 21076 textile units are spread all over India. ${ }^{6}$ A large quantity of water is utilized by textile industries during the production of textiles. As a result, a significant quantity of industrial wastewater is produced, which needs to be treated appropriately before its safe disposal. This industrial wastewater is treated in effluent treatment plant units.

During this effluent treatment process, a large amount of sludge is generated in various stages or processes - namely, chemical coagulation (i.e. addition of chemical coagulants), flocculation (i.e. formation of flocs) and liquid or solid separation. ${ }^{1}$ It is estimated that in India the textile industry generates an abundant quantity of textile effluent treatment plant (TETP) sludge - namely, around 


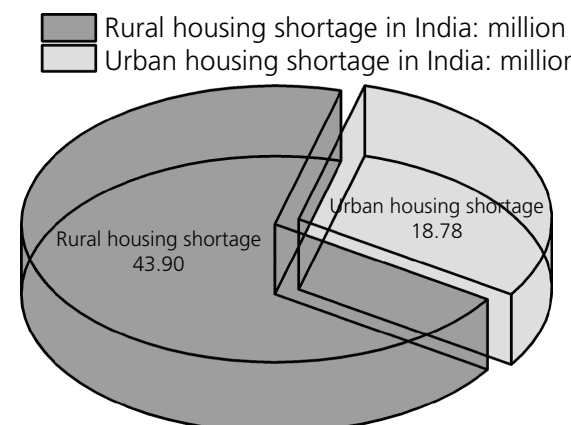

Total housing shortage in India $=62.68$ million

(a)

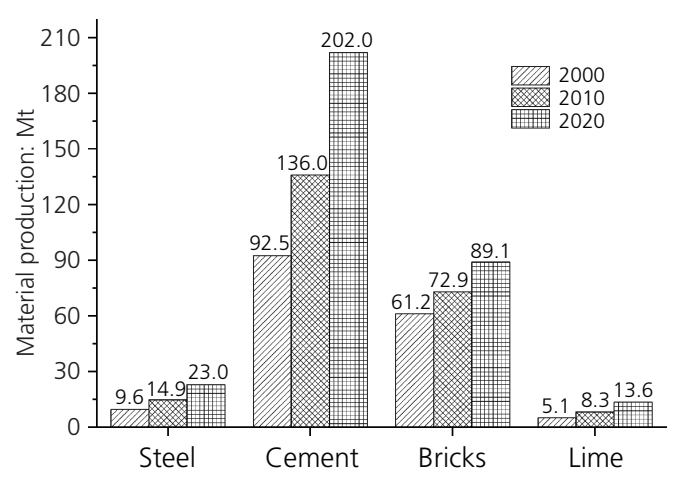

(b)

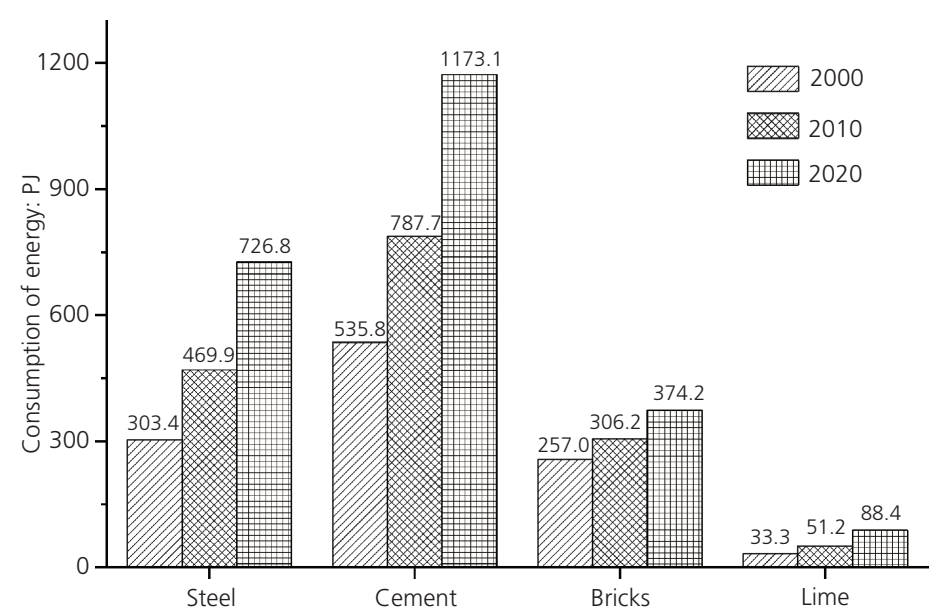

(c)

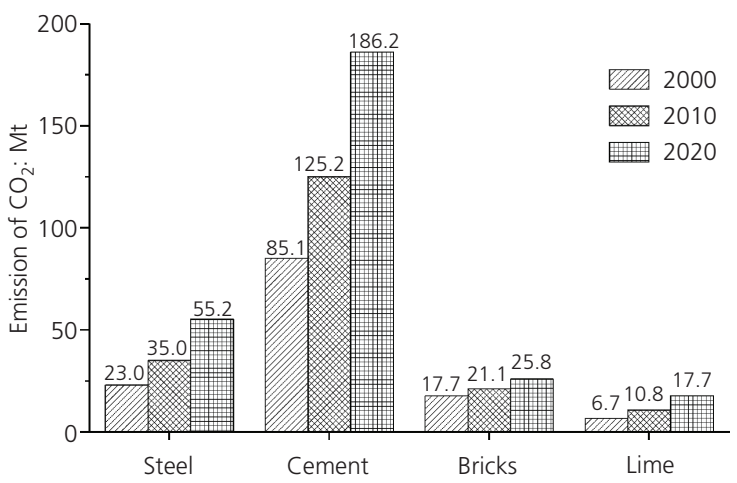

(d)

Figure 1. (a) Housing shortage in India; (b) material production in India; (c) energy consumption in India; (d) carbon dioxide emission in India

$70-80 \mathrm{Mt} /$ day. $^{7,8}$ It sometimes contains heavy metals, impurities and inorganic salts, which are then disposed of in landfills, thereby causing environmental pollution. Hence, many researchers have attempted to reuse and recycle this sludge to develop cost-effective sustainable construction materials that can reduce the toxic effect on groundwater and soil, incurred due to leaching out of heavy metals, and also provide an economic solution to fulfill the demand for construction materials. The present study delineates past research studies on the utilization of TETP sludge into environmentally friendly, modern, sustainable construction materials and identifies the prominent areas for further research. Using low-cost effluent sludge waste as a base material for manufacturing sustainable construction materials would not only solve the environmental pollution problem but would also make the construction facilities sustainable and cost effective.

\section{Development of sustainable construction materials using TETP sludge}

\subsection{Methodology for the development of sustainable construction materials}

Figure 2 shows the methodology for the development of sustainable construction materials such as mortar, concrete, clay bricks and paver blocks. To start with, a sample of open-air-dried textile sludge sample from the textile industry is collected and then dried in an oven at a temperature of $105^{\circ} \mathrm{C}$ until the net weight becomes steady ${ }^{6}$ or the sample can be used directly. To decrease the size of large and irregular particles, the dried samples are then crushed. Similarly, other raw materials such as cement, fine aggregate, coarse aggregate and clay are collected (Tables 1 and 2). Characterization of the collected raw materials is then carried out using scanning electron microscopy (SEM), X-ray fluorescence (XRF), X-ray diffraction (XRD), thermogravimetric analysis or thermal gravimetric analysis (TGA) and so on. The raw materials are then mechanically/hand-mixed until a homogenous mixture is obtained. The mixture is then pressed or molded as per the requirements at various proportions (Tables 3-6). The specimens are then dried in the open air or the oven, depending on the type of product developed. The dried specimens or products are then fired in a kiln or cured as per the requirements. To determine the mechanical properties of the developed sustainable materials, samples of specimens are then subjected to various tests such as compressive strength, density, split tensile strength, flexural strength, water absorption, shrinkage and porosity tests as specified in the various standards depending on the type of development of 


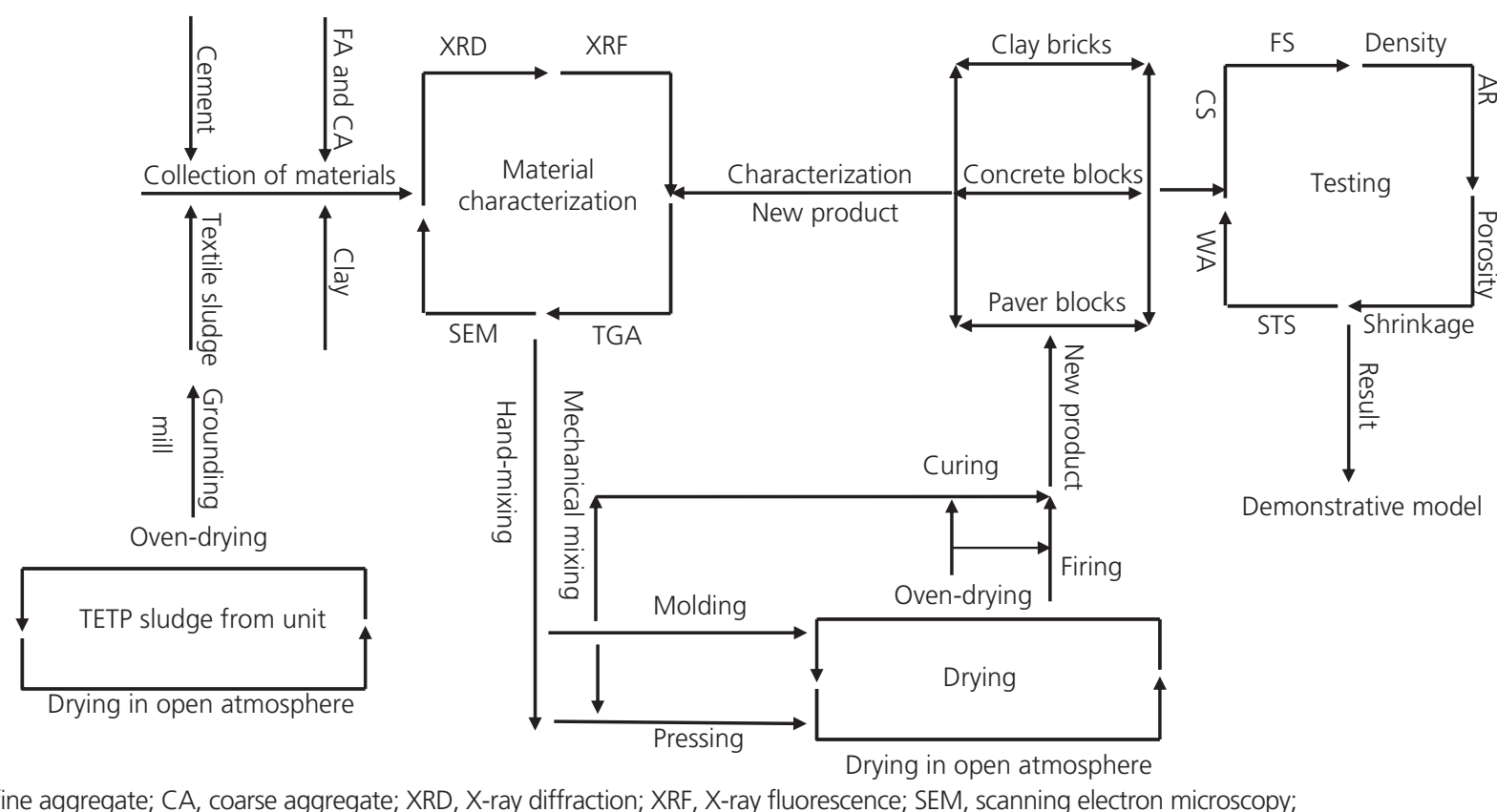

FA, fine aggregate; CA, coarse aggregate; XRD, X-ray diffraction; XRF, X-ray fluorescence; SEM, scanning electron microscopy;

TGA, thermogravimetric analysis; CS, compressive strength; FS, flexural strength; WA, water absorption; AR, abrasion resistance; STS, split tensile strength

Figure 2. Methodology for development of sustainable construction material based on the literature ${ }^{1-65}$

sustainable materials. Subsequently, characterization of the developed product can then be carried out. A demonstrative reallife model can then be prepared using a developed sustainable construction material to monitor the performance.

\subsection{Material characterization}

\subsubsection{Scanning electron microscopy}

SEM analysis helps analyze the morphological characteristics of the material. TETP sludge has been found to consist of particles

Table 1. Various elemental analyses carried out by past researchers

\begin{tabular}{|c|c|c|c|}
\hline Number & Test & Equipment & Description \\
\hline 1 & $\begin{array}{l}\text { Scanning electron } \\
\text { microscopy } \\
\text { m,10-12,20,34,66 }\end{array}$ & $\begin{array}{l}\text { Hitachi S-3000H, }{ }^{6} \text { JSM-6510LV microscope, } \\
\text { Shimadzu SS } 550 \text { microscope, }{ }^{20} \text { Hitachi model } \\
\text { S-3400N }\end{array}$ & $\begin{array}{l}\text { Examines the morphological characteristics of pure } \\
\text { clay samples, textile sludge samples, }{ }^{34} \text { bricks } \\
\text { replaced with sludge, }{ }^{6} \text { mortar specimens and } \\
\text { sludge-incorporated mortar specimens }{ }^{12,13}\end{array}$ \\
\hline 2 & $\begin{array}{l}\text { Fourier transform infrared } \\
\text { (FTIR) spectroscopy } \\
\text { analysis }^{6}\end{array}$ & $\begin{array}{l}\text { FTIR spectroscope (FTIR-2000, PerkinElmer) using } \\
\text { the potassium bromide }(\mathrm{KBr}) \text { pellet } \text { method }^{6}\end{array}$ & $\begin{array}{l}\text { Detects the surface functional groups of pure clay } \\
\text { samples, textile sludge samples and bricks } \\
\text { replaced with textile sludge }\end{array}$ \\
\hline 3 & $\begin{array}{l}\text { X-ray fluorescence } \\
(\mathrm{XRF})^{10,11,15-18}\end{array}$ & $\begin{array}{l}\text { Phillips PW } 2404 \text { XRF spectrometer, }{ }^{11} \text { Edax Inc. } \\
\text { Eagle III XRF spectrometer, }{ }^{15} \text { Hach } \\
\text { spectrophotometer, Shimadzu XRF-1800 XRF } \\
\text { spectrophotometer, }^{16} \text { Philips PW } 1480 \text { XRF }_{\text {spectrometer }^{18}}\end{array}$ & $\begin{array}{l}\text { Detects the chemical composition of textile } \\
\text { sludge }^{11,18} \text { and its inorganic elements, } \\
\text { particularly the heavy metals present in it }{ }^{16}\end{array}$ \\
\hline 4 & $\begin{array}{l}\text { Thermogravimetric } \\
\text { analysis }{ }^{11,15,17,20,41}\end{array}$ & $\begin{array}{l}\text { PerkinElmer Diamond thermogravimetric and } \\
\text { differential thermal analyzer, }{ }^{15} \text { PerkinElmer TGA7 } \\
\text { analyzer, }{ }^{19} \text { Shimadzu TA-50 equipment (Tokyo), }{ }^{20} \\
\text { TG-DTA } 2000 \text { SA }^{41}\end{array}$ & $\begin{array}{l}\text { Helps understand the effect of temperature on } \\
\text { textile mill sludge and soil }{ }^{11,19,41}\end{array}$ \\
\hline 5 & $\begin{array}{l}\text { Atomic absorption } \\
\text { spectrometry }^{12,19,21,66}\end{array}$ & $\begin{array}{l}\text { Atomic absorption spectrophotometer, }{ }^{12,66} \\
\text { Thermosolar } 2 \text { ASS spectra atomic absorption } \\
\text { spectrophotometer }^{19}\end{array}$ & $\begin{array}{l}\text { Determines heavy metals in raw materials }{ }^{19} \text { and } \\
\text { detects lead }(\mathrm{Pb}) \text {, chromium }(\mathrm{Cr}) \text {, copper }(\mathrm{Cu}) \\
\text { and zinc content in sludge-incorporated } \text { mortar }^{12}\end{array}$ \\
\hline 6 & $\begin{array}{l}\text { X-ray } \\
\text { diffraction } \\
\end{array}$ & $\begin{array}{l}\text { X'Pert HighScore Plus, }{ }^{13} X^{\prime} \text { Pert Pro (PANalytical } \\
\text { B.V.), }{ }^{15} X^{\prime} \text { Tra X-ray diffractometer }{ }^{66}\end{array}$ & $\begin{array}{l}\text { Determines the mineralogical composition of } \\
\text { textile sludge }{ }^{14,36,64} \text { and phase changes in } \\
\text { specimens prepared using it }{ }^{13,15,66}\end{array}$ \\
\hline 7 & $\begin{array}{l}\text { Energy-dispersive X-ray } \\
\text { spectroscopy }^{30,66}\end{array}$ & Horiba EX-205 66 & $\begin{array}{l}\text { Determines the elemental composition of textile } \\
\text { sludge }^{30} \text { and the samples prepared using it }{ }^{66}\end{array}$ \\
\hline 8 & $\begin{array}{l}\text { Spatial scale surface } \\
\text { morphological analysis }\end{array}$ & JXA-8900JR electron probe microanalyzer ${ }^{41}$ & $\begin{array}{l}\text { Investigates the effect of sludge and waste glass } \\
\text { additions on brick specimens }{ }^{41}\end{array}$ \\
\hline
\end{tabular}




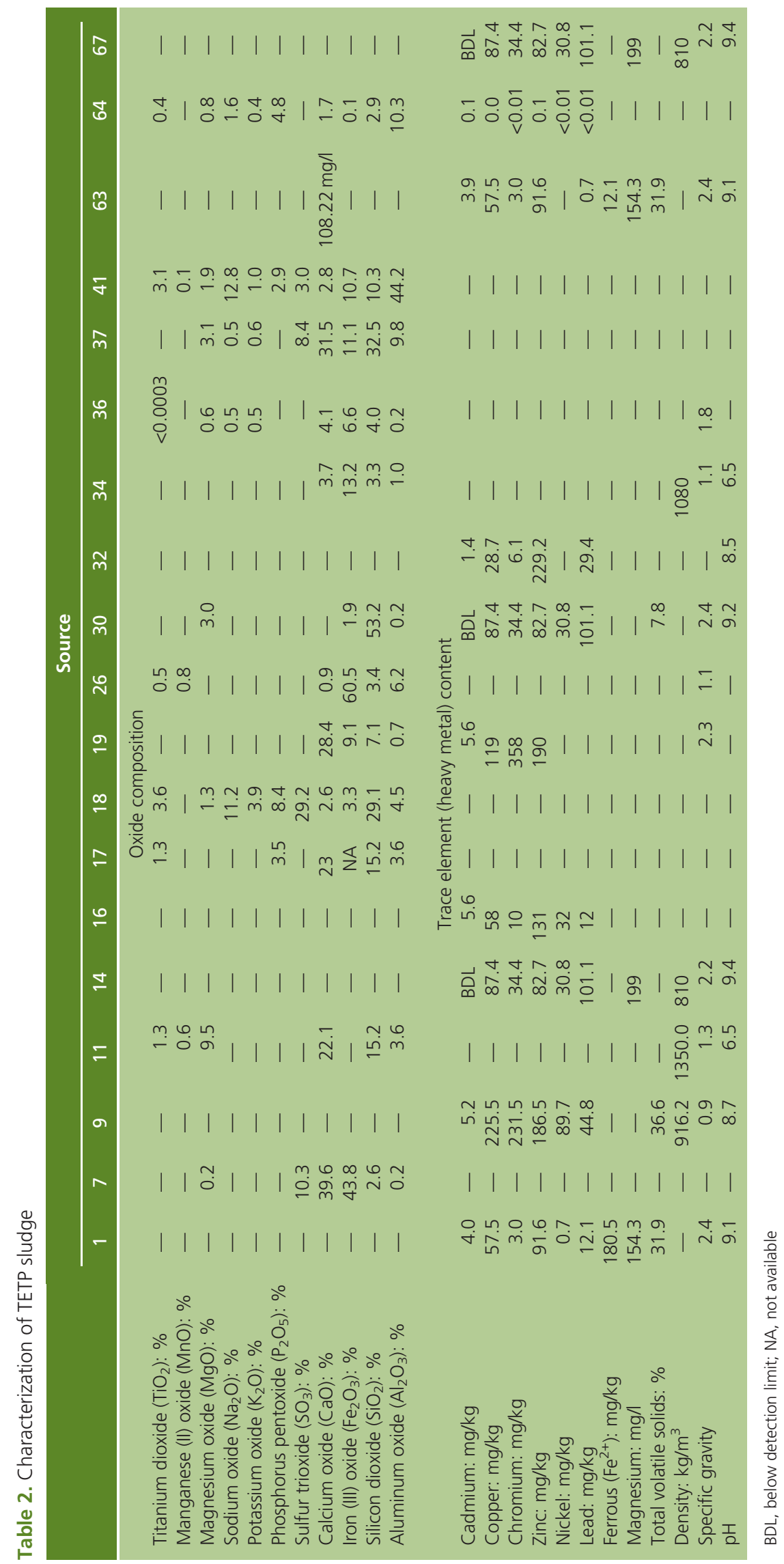


Table 3. Development of sustainable cement sludge blocks/mortar

\begin{tabular}{|c|c|c|c|c|c|c|}
\hline Source & Type of product & $\begin{array}{l}\text { Size of sample: } \\
\mathrm{mm}\end{array}$ & $\begin{array}{l}\text { TETP sludge } \\
\text { replaced with }\end{array}$ & Used: \% & Curing & $\begin{array}{l}\text { Various tests } \\
\text { conducted }\end{array}$ \\
\hline $\begin{array}{l}\text { Patel and } \\
\text { Pandey }\end{array}$ & Cement-sludge blocks & $70.6 \times 70.6 \times 70.6$ & Cement & $30-70$ & $\begin{array}{c}\text { Moist condition: } 24 \mathrm{~h} \text { at room } \\
\text { temperature }\left(27-29^{\circ} \mathrm{C}\right) \text { and relative } \\
\text { humidity }(\mathrm{RH}) \text { of } 92 \%\end{array}$ & $\mathrm{CS}, \mathrm{BD}, \mathrm{LT}$ \\
\hline $\begin{array}{l}\text { Jahagirdar } \\
\text { et } a l^{10}\end{array}$ & Cement-sludge blocks & $70.6 \times 70.6 \times 70.6$ & Cement & $20-90$ & Water tank: 28 days & $C S, B D, L T$ \\
\hline $\begin{array}{l}\text { Rahman } \\
\text { et al. }{ }^{12}\end{array}$ & Mortar specimens & $\begin{array}{l}50.8 \times 50.8 \times 50.8 \\
304.8 \times 25.4 \times 25.4\end{array}$ & Cement/sand & $\begin{array}{l}10-50 \\
\text { and } \\
20-80\end{array}$ & 28 days & $\begin{array}{l}\text { CS, WA, FS, } \\
\text { LT, porosity }\end{array}$ \\
\hline Goyal et al..$^{13}$ & $\begin{array}{l}\text { Cement-sludge pastes } \\
\text { and cement-sludge } \\
\text { mortar mixes }\end{array}$ & $70.6 \times 70.6 \times 70.6$ & Cement & $5-20$ & $\begin{array}{c}\text { Moist curing: } 28 \text { days followed by } \\
\text { air curing }\end{array}$ & $\begin{array}{l}\text { CS, STS, WA, } \\
\text { RCPT, } \\
\text { sorptivity test }\end{array}$ \\
\hline $\begin{array}{l}\text { Vellingiri } \\
\text { et al. }{ }^{14}\end{array}$ & Mortar cubes & $70.6 \times 70.6 \times 70.6$ & Cement & $10-30$ & 28 and 56 days & CS, WA \\
\hline $\begin{array}{l}\text { Patel and } \\
\text { Pandey }{ }^{21}\end{array}$ & Cement-sludge blocks & $70.6 \times 70.6 \times 70.6$ & Cement & $30-70$ & $\begin{array}{l}14 \text { and } 28 \text { days (at ambient } \\
\text { temperature, } \mathrm{RH} \text { of } 70 \% \text { ) }\end{array}$ & $\mathrm{BD}, \mathrm{CS}, \mathrm{LT}$ \\
\hline $\begin{array}{l}\text { Jeevanandam } \\
\text { et al. }{ }^{22}\end{array}$ & Cement-mortar cubes & $70.6 \times 70.6 \times 70.6$ & Cement & $10-60$ & $\begin{array}{l}\text { 7, } 14 \text { and } 28 \text { days (at ambient } \\
\text { temperature, RH of } 60 \% \text { ) }\end{array}$ & $\begin{array}{l}\mathrm{CS}, \mathrm{LT}, \mathrm{pH}, \\
\text { electrical } \\
\text { conductivity }\end{array}$ \\
\hline Arul et al. ${ }^{23}$ & Cement-mortar cubes & $70.6 \times 70.6 \times 70.6$ & Cement & $5-30$ & 7,14 and 28 days & $C S, W A, B D$ \\
\hline
\end{tabular}

BD, block density; CS, compressive strength; FS, flexural strength; LT, leachate test; RCPT, rapid chloride permeability test; STS, split tensile strength; WA, water absorption

Table 4. Development of sustainable concrete

\begin{tabular}{|c|c|c|c|c|c|c|}
\hline Source & Type of product & Size of sample: mm & $\begin{array}{l}\text { TETP sludge } \\
\text { replaced with }\end{array}$ & $\begin{array}{l}\text { Used: } \\
\%\end{array}$ & Curing: days & $\begin{array}{l}\text { Various tests } \\
\text { conducted }\end{array}$ \\
\hline $\begin{array}{l}\text { Balasubramanian } \\
\text { et al. }{ }^{1}\end{array}$ & Solid concrete blocks & $400 \times 150 \times 200$ & Cement & 10-30 & 3,7 and 28 & $\begin{array}{l}\mathrm{CS}, \mathrm{WA}, \mathrm{BD}, \\
\text { moisture } \\
\text { movement }\end{array}$ \\
\hline Rahman et al. ${ }^{12}$ & Concrete specimens & $152.4 \times 152.4 \times 152.4$ & Sand & 20-100 & 28 & $\begin{array}{l}\text { CS, FS, WA, LT, } \\
\text { porosity }\end{array}$ \\
\hline Arul et al. ${ }^{23}$ & Concrete cubes & $150 \times 150 \times 150$ & Cement & $5-30$ & 7,14 and 28 & $\begin{array}{l}\text { CS, STS, FS, } \\
\text { WA, BD }\end{array}$ \\
\hline Zhan and Poon ${ }^{26}$ & Concrete blocks & $\begin{array}{c}70 \times 70 \times 70,25 \times 25 \times \\
285\end{array}$ & Sand & $5-30$ & $\begin{array}{l}\text { Wrapped with plastic films } \\
\text { for moist curing: } 7 \text { and } 28\end{array}$ & $\mathrm{CS}, \mathrm{ST}, \mathrm{LT}$ \\
\hline $\begin{array}{l}\text { Loganayagan } \\
\text { et al..27 }\end{array}$ & Concrete blocks & $150 \times 150 \times 150$ & Sand & $5-20$ & 7 and 28 & CS \\
\hline Altidis et al. ${ }^{29}$ & Concrete specimens & 50 diameter by 10 height & Sand & $3-7$ & mber: 7 and 28 & CS, WA \\
\hline Anandh et al. ${ }^{31}$ & Concrete specimens & $\begin{array}{c}150 \times 150 \times 150,200 \times \\
100,500 \times 100 \times 100\end{array}$ & Cement & $5-30$ & - & FS, CS, STS \\
\hline Kaur et al. ${ }^{33}$ & Concrete specimens & $\begin{array}{c}150 \times 150 \times 150,70.6 \times \\
70.6 \times 70.6\end{array}$ & Sand & $5-55$ & 7,14 and 28 & $\begin{array}{l}C S, A R \text {, acid } \\
\text { attack }\end{array}$ \\
\hline Kulkarni et al. ${ }^{34}$ & Concrete blocks & $150 \times 150 \times 150$ & Sand & $4-36$ & - & $C S, B D$ \\
\hline Sandesh et al. ${ }^{36}$ & Concrete blocks & - & Cement & $5-10$ & 3,7 and 28 & CS, STS, FS, WA \\
\hline Kaur et al. ${ }^{38}$ & Concrete blocks & $150 \times 150 \times 150$ & Sand & $15-55$ & Curing tank: 7,14 and 28 & CS \\
\hline $\begin{array}{l}\text { Mariappan } \\
\text { et al. }{ }^{53}\end{array}$ & Concrete specimens & $\begin{array}{c}150 \times 150 \times 150,100 \times \\
100 \times 500\end{array}$ & Cement & $10-20$ & - & CS, STS, FS \\
\hline $\begin{array}{l}\text { Joseph and } \\
\text { Kumar }^{54}\end{array}$ & Concrete specimens & $\begin{array}{c}150 \times 150 \times 150 \\
\text { diameter } 150 \text { and length } \\
300\end{array}$ & Cement & $5-15$ & 28 & CS, STS \\
\hline Pradeepa et al. ${ }^{56}$ & Concrete blocks & $150 \times 150 \times 150$ & Sand & $5-15$ & Curing tank: 7,14 and 28 & CS \\
\hline Prabhu et al. ${ }^{57}$ & Concrete blocks & $150 \times 150 \times 150$ & Sand & $30-50$ & Curing tank: 28 & CS, FS \\
\hline Kaur and Singh ${ }^{58}$ & Concrete blocks & $100 \times 100 \times 100$ & Cement & $5-35$ & Curing tank: 7,14 and 28 & CS \\
\hline Sakthivel et al. ${ }^{59}$ & Concrete specimens & $150 \times 150 \times 150$ & Sand & $10-30$ & - & CS, STS \\
\hline
\end{tabular}

$A R$, abrasion resistance; $B D$, block density; $C S$, compressive strength; FS, flexural strength; LT, leachate test; ST, shrinkage test; STS, split tensile strength; WA, water absorption 
Green Materials

Volume 10 issue 4
Sustainable building materials using

textile effluent treatment plant sludge:

a review

Patil, Raut, Ralegaonkar and Madurwar

Table 5. Development of sustainable clay bricks

\begin{tabular}{|c|c|c|c|c|c|c|c|}
\hline Source & $\begin{array}{l}\text { Type of } \\
\text { product }\end{array}$ & $\begin{array}{c}\text { Size of sample: } \\
\text { mm }\end{array}$ & $\begin{array}{l}\text { TETP sludge } \\
\text { replaced with }\end{array}$ & $\begin{array}{l}\text { Used: } \\
\%\end{array}$ & Drying & Firing & $\begin{array}{l}\text { Various tests } \\
\text { conducted }\end{array}$ \\
\hline $\begin{array}{l}\text { Balasubramanian } \\
\text { et al. }{ }^{1}\end{array}$ & Clay bricks & $190 \times 90 \times 90$ & Clay & $10-30$ & - & - & CS, WA, efflorescence \\
\hline Begum et al. ${ }^{6}$ & Clay bricks & $210 \times 100 \times 75$ & Clay & $3-50$ & $\begin{array}{c}\text { Open } \\
\text { atmosphere: } \\
24 \mathrm{~h}\end{array}$ & $1000^{\circ} \mathrm{C}$ - brick kiln & $\begin{array}{l}\text { CS, WA, WL, } \\
\text { efflorescence, density }\end{array}$ \\
\hline $\begin{array}{l}\text { Jahagirdar } \\
\text { et al. }{ }^{11}\end{array}$ & Clay bricks & $70 \times 70 \times 70$ & Clay & $5-35$ & $\begin{array}{l}\text { Air-drying in } \\
\text { lab: } 2 \text { days; } \\
\text { and sunlight: } 4 \\
\text { days }\end{array}$ & $\begin{array}{c}600,700 \text { and } 800^{\circ} \mathrm{C} \\
\text { - muffle furnace }(8, \\
16 \text { and } 24 \mathrm{~h})\end{array}$ & $\begin{array}{l}\text { CS, WA, density, } \\
\text { efflorescence }\end{array}$ \\
\hline Anwar et al. ${ }^{16}$ & Clay bricks & $121 \times 114.3 \times 70$ & Clay & $0.5-5.25$ & $\begin{array}{l}\text { Air-drying: } \\
10 \text { days }\end{array}$ & $\begin{array}{l}1050^{\circ} \mathrm{C} \text { - Hoffman } \\
\text { kiln burning } 8 \text { days }\end{array}$ & CS, WA, LT, ST \\
\hline $\begin{array}{l}\text { Jahagirdar } \\
\text { et al. }{ }^{17}\end{array}$ & Clay bricks & $70 \times 70 \times 70$ & Clay & $5-35$ & $\begin{array}{l}\text { Air-drying in } \\
\text { lab: few days; } \\
\text { and sunlight: } \\
4 \text { days }\end{array}$ & $\begin{array}{l}600,700 \text { and } 800^{\circ} \mathrm{C} \\
\text { - muffle furnace }(8, \\
16 \text { and } 24 \mathrm{~h}, \\
\text { respectively) }\end{array}$ & CS, WA, density \\
\hline $\begin{array}{l}\text { Jewaratnam and } \\
\text { Samat }^{18}\end{array}$ & Clay bricks & $100 \times 100 \times 15$ & Clay & $5-20$ & $\begin{array}{c}\text { Oven: } 24 \mathrm{~h} \text { at } \\
105^{\circ} \mathrm{C}\end{array}$ & $\begin{array}{l}950 \text { and } 118^{\circ} \mathrm{C}- \\
\text { chamber furnace }\end{array}$ & CS, WA, ST, density \\
\hline Baskar et al. ${ }^{19}$ & Clay bricks & $70 \times 70 \times 70$ & Clay & $3-30$ & $\begin{array}{l}\text { Open } \\
\text { atmosphere: } \\
24 \mathrm{~h} \text {; and } \\
\text { oven: } 6 \mathrm{~h} \text { at } \\
110^{\circ} \mathrm{C}\end{array}$ & $\begin{array}{l}200-800^{\circ} \mathrm{C}-\text { muffle } \\
\text { furnace }(2-8 \mathrm{~h})\end{array}$ & CS, WA, ST \\
\hline $\begin{array}{l}\text { Priyadharshini } \\
\text { and Kavisri }{ }^{39}\end{array}$ & Clay bricks & $90 \times 90 \times 190$ & Clay & $5-20$ & $\begin{array}{c}\text { Open } \\
\text { atmosphere: } \\
\text { 10-12 days }\end{array}$ & $\begin{array}{l}900^{\circ} \mathrm{C}-\text { muffle } \\
\text { furnace }\end{array}$ & $\begin{array}{l}\text { CS, WA, density, } \\
\text { efflorescence }\end{array}$ \\
\hline $\begin{array}{l}\text { Mary and } \\
\text { Sreeja }^{40}\end{array}$ & Clay bricks & $75 \times 33 \times 33$ & Clay & $0-6.66$ & $\begin{array}{l}\text { Sunlight: } 4 \\
\text { days }\end{array}$ & $\begin{array}{l}400,500 \text { and } 600^{\circ} \mathrm{C} \\
\text { - muffle furnace }\end{array}$ & CS \\
\hline Rahman et al. ${ }^{41}$ & Clay bricks & $\varnothing 30 \times 30$ height & Clay & $10-40$ & $\begin{array}{c}\text { Open } \\
\text { atmosphere: } 1 \\
\text { day; or oven: } \\
\text { overnight }\end{array}$ & $\begin{array}{l}1150^{\circ} \mathrm{C}-\text { muffle } \\
\text { furnace }(2 \mathrm{~h})\end{array}$ & CS, WA, WL, LT, ST \\
\hline Hossain et al. ${ }^{61}$ & Clay bricks & $150 \times 75 \times 25$ & Clay & $10-50$ & $\begin{array}{l}\text { Air-drying and } \\
\text { sunlight }\end{array}$ & $\begin{array}{l}450^{\circ} \mathrm{C}-\text { muffle } \\
\text { furnace }(24 \mathrm{~h})\end{array}$ & $\begin{array}{l}\text { WL, WA, FS, WA, ST, } \\
\text { density, bending } \\
\text { modulus, impact } \\
\text { strength, electrical } \\
\text { resistivity }\end{array}$ \\
\hline
\end{tabular}

CS, compressive strength; FS, flexural strength; LT, leachate test; ST, shrinkage test; WA, water absorption; WL, weight loss

Table 6. Development of sustainable paver blocks

\begin{tabular}{|c|c|c|c|c|c|c|}
\hline Source & Type of product & Size of sample & $\begin{array}{l}\text { TETP sludge } \\
\text { replaced with }\end{array}$ & $\begin{array}{l}\text { Used: } \\
\%\end{array}$ & $\begin{array}{l}\text { Curing: } \\
\text { days }\end{array}$ & $\begin{array}{l}\text { Various tests } \\
\text { conducted }\end{array}$ \\
\hline $\begin{array}{l}\text { Balasubramanian } \\
\text { et al. }{ }^{1}\end{array}$ & Pavements blocks & $\begin{array}{l}\text { Hexagonal shape of } \\
39000 \mathrm{~mm}^{2}\end{array}$ & Cement & $10-30$ & - & CS, WA \\
\hline Patel et al. ${ }^{7}$ & $\begin{array}{l}\text { Rubber mould paver } \\
\text { blocks }\end{array}$ & $60 \mathrm{~mm}$ thick & Cement & $5-40$ & 28 & $C S, W A, A R$ \\
\hline Narayan and Supriya ${ }^{45}$ & Paver blocks & $200 \times 100 \times 60 \mathrm{~mm}$ & Cement & $10-30$ & 7 and 28 & $C S, W A$ \\
\hline $\begin{array}{l}\text { Velumani and } \\
\text { Senthilkumar }\end{array}$ & Paver blocks & $\begin{array}{c}\text { Zigzag pattern }(229 \times \\
110 \mathrm{~mm})\end{array}$ & Cement & $10-35$ & $\begin{array}{l}\text { Water tank: } \\
28\end{array}$ & $C S, W A, F S, A R$ \\
\hline Indumathi et al. ${ }^{47}$ & Paver blocks & - & Cement & $20-60$ & $\begin{array}{c}7,14 \text { and } \\
28\end{array}$ & CS \\
\hline Kishore $^{48}$ & Paver blocks & $200 \times 120 \times 80 \mathrm{~mm}$ & Cement & $10-40$ & - & CS, WA, FS \\
\hline Jayakumar et al. ${ }^{62}$ & Paver blocks & $200 \times 120 \times 60 \mathrm{~mm}$ & Cement & $10-40$ & 7 and 28 & WA, CS, FS, RCPT \\
\hline
\end{tabular}

$A R$, abrasion resistance; CS, compressive strength; FS, flexural strength; RCPT, rapid chloride permeability test; WA, water absorption 
of various shapes and sizes ${ }^{9}$ and is fibrous. ${ }^{6}$ The particles present in sludge have been found to be larger than clay particles. ${ }^{6}$ Sludge particles show predominance of spherical particles in the form of agglomerates with a diameter ranging from 1 to $40 \mu \mathrm{m} .{ }^{9}$ Analysis of textile mill sludge using the electron-dispersive technique under SEM also exhibited the absence of heavy metals. ${ }^{10,11}$ Mercury $(\mathrm{Hg})$ and molybdenum (Mo) were discovered but in a smaller amount - namely, below $0.4 \%{ }^{11}$

SEM images also showed that samples of textile-sludgeincorporated clay bricks had more pore spaces than samples of crushed brick powder obtained from pure clayey brick. Consequently, the quantity of absorbed water increased. ${ }^{6} \mathrm{~A}$ mixture of granular and fibrous materials was seen in SEM images of bricks with $15 \%$ sludge.

In cement sludge mortar specimens, the major products that were found in the control sample $(100 \%$ cement and $0 \%$ sludge $)$ were calcium silicate hydrate $(\mathrm{CSH})$ gel and calcium hydroxide $(\mathrm{Ca}$ $\left.(\mathrm{OH})_{2}\right)$. However, when cement was replaced with textile sludge in greater quantities, a more porous microstructure was found, with ettringite and voids, and a lower amount of CSH gel. The surface structure of the cement sand mortar was seen to be homogeneous and dense. ${ }^{12}$ However, higher heterogeneity in the structure was seen due to the addition of sludge in the composition. This heterogeneity in the microstructure of the mortar caused a significant reduction in the strength. Lack of hydration was also clearly observed in textile sludge mixes.

\subsubsection{X-ray diffraction}

Analysis of XRD peaks showed that textile effluent sludge mostly consists of calcite $\left(\mathrm{CaCO}_{3}\right)$, quartz $\left(\mathrm{SiO}_{2}\right)$, ferric oxide, vaterite $\left(\mathrm{CaCO}_{3}\right)$, calcium hydroxide and gypsum $\left.\left(\mathrm{Ca}\left(\mathrm{SO}_{4}\right)\left(\mathrm{H}_{2} \mathrm{O}\right)_{2}\right)\right)^{9,13,14}$ The presence of calcium $(\mathrm{Ca})$ compounds and gypsum in textile sludge confirms its potential as a construction material.

Microstructural analysis of mortar specimens after a compressive strength test showed $\mathrm{CSH}$, calcium silicates $\left(\mathrm{C}_{3} \mathrm{~S}\right.$ and $\left.\mathrm{C}_{2} \mathrm{~S}\right)$, portlandite, calcite and quartz. ${ }^{13}$ The addition of textile sludge in mortar mixes showed no noticeable qualitative changes in the phases of cement hydration products. The hydration of mortar mixes was affected by the percentage increase of textile sludge from 0 to $20 \%$. When textile sludge was incorporated into the composition, the peaks of calcium carbonate and calcium silicates were found to have higher intensities, while the hydration products, such as CSH and calcium hydroxide, had lower intensities. It was observed that the addition of $20 \%$ textile sludge resulted in lesser hydration reaction and lesser pozzolanic action at later ages, hence leading to a loss in the performance of mortars as confirmed by the strength tests and permeation behavior of the specimens. Thus, optimum replacement of up to $5 \%$ textile sludge in cement mortar mixes was suggested.

The XRD pattern of a cement sludge specimen with $40 \%$ textile sludge showed peaks of unreacted $\mathrm{C}_{2} \mathrm{~S}$ and $\mathrm{C}_{3} \mathrm{~S}$ along with ettringite peaks. ${ }^{9}$ In the XRD pattern, the portlandite peak was seen absent, thereby indicating hydration retardation. Gehlenite hydrate peaks have also been observed. Thus, it can be inferred that the addition of sludge above $40 \%$ resulted in hydration retardation and resulted in an adverse effect on gel formation.

Peaks of quartz along with traces of microcline $\left(\mathrm{KAlSi}_{3} \mathrm{O}_{8}\right)$ and hematite $\left(\mathrm{Fe}_{2} \mathrm{O}_{3}\right)$ were detected in the XRD pattern of sludgeincorporated clay bricks for a sludge proportion of $20 \%$, which was found similar to the chemical composition of soil and textile sludge. ${ }^{15}$ Hence, an optimum mix of $20 \%$ textile sludge is being suggested for the manufacturing of bricks.

\subsubsection{X-ray fluorescence}

Elemental analysis such as determination of carbon (C), hydrogen $(\mathrm{H})$, nitrogen $(\mathrm{N})$ and sulfur $(\mathrm{S})$ contents $^{15}$ and the main chemical composition of raw materials such as textile sludge and soil can be carried out using the XRF technique. Toxic metals such as arsenic, chromium, cadmium and lead were observed in textile sludge but at a lower concentration. ${ }^{16}$ Many researchers have found that textile sludge contains a smaller quantity of silicon dioxide $\left(\mathrm{SiO}_{2}\right)$ than ordinary Portland cement and fly ash, thus indicating its lack of binding properties. ${ }^{10,11,17}$ Meanwhile, the presence of a significant amount of aluminum oxide $\left(\mathrm{Al}_{2} \mathrm{O}_{3}\right)$, calcium oxide $(\mathrm{CaO})$ and iron (II) oxide $(\mathrm{FeO})$ indicates its potential as a building material. Therefore, to enhance its binding properties, the addition of fly ash is recommended, as it contains a significant amount of silicon dioxide. ${ }^{10}$ The presence of a significant amount of sulfur trioxide $\left(\mathrm{SO}_{3}\right)$ in textile sludge has also been reported in other research studies, ${ }^{18}$ which indicates good binding properties when incorporated into building materials. This indicates that the chemical composition of textile sludge varies by industry. It also varies with the chemical used and dosage applied during the treatment process of textile wastewater. ${ }^{16}$ Thus, by looking at the results of XRF analysis, it can be concluded that TETP sludge has the potential to be used in developing sustainable construction materials.

\subsubsection{Thermogravimetric analysis}

Thermogravimetry (TG) provides information on the thermal behavior of raw materials such as textile sludge and clay ${ }^{19}$ and samples of textile-sludge-incorporated products such as clay bricks. Three distinct patterns of variance in weight loss with temperature were seen in a TG plot of textile sludge. There were three different peaks at 295,380 and $790^{\circ} \mathrm{C}$ with respect to the derivative weight loss. The presence of volatile organic matter in textile sludge may be the reason for this weight loss. Similarly, three main peaks in the TGA curve of the textile sludge sample, corresponding to weight loss, were observed. ${ }^{20}$ The first one occurred until $223^{\circ} \mathrm{C}$, and it corresponds to the loss of physically adsorbed water. A further weight loss of $75 \%$ was observed until $304^{\circ} \mathrm{C}$, which corresponds to the dehydration of hydroxides and the presence of a high water content. Lastly, a weight loss near $600^{\circ} \mathrm{C}$ was observed, and it can be attributed to the presence of volatile constituents. In the DSC curve of the sludge sample, there 
was also a pronounced endothermic peak at $100^{\circ} \mathrm{C}$, which is related to water loss in the sample. Whereas, a smaller portion of weight loss was reported in another research study at a similar range of temperatures - that is, $400-800^{\circ} \mathrm{C} .{ }^{15}$

Thus, from the TGA curves of textile sludge, it can be inferred that the burning of volatile matter present in textile sludge might affect the strength, density and water absorption of sludgeincorporated sustainable materials due to an increase in the pores of materials. Similar results have been reported by past researchers, such as voids being observed in sludge-incorporated clay bricks due to the burning of organic matter present in TETP sludge. ${ }^{11,17}$ With the increase in temperature, the weight of TETP sludge was found to reduce, resulting in a porous brick structure with lower compressive strength and increased value of water absorption. A weight loss of $30-40 \%$ was observed within the temperature range $600-800^{\circ} \mathrm{C}$ due to the presence of organic matter. Thus, for the development of sustainable construction materials, optimal usage of TETP sludge was suggested by past researchers.

\subsection{Study of sustainable mortar incorporating TETP sludge}

In Figure 3, maximum strength was observed in control specimens compared with a specimen cast with textile sludge. As the percentage substitution of textile sludge as a partial replacement of cement in cement-sludge specimen/mortar is increased, the compressive strength decreases. ${ }^{9,13,21-23}$ A maximum of $62 \%$ reduction in strength is observed. It is evident from Table 2 that textile sludge contains a lower amount of calcium oxide compared with cement, due to which the hydration process slows down and results in an increase in the setting time, thus contributing to the reduction in the compressive strength of the mortar specimens. Furthermore, it does not show adequate pozzolanic activity and binding capacity due to the lower amount of silica present; ${ }^{12}$ thus, satisfactory later strength was not

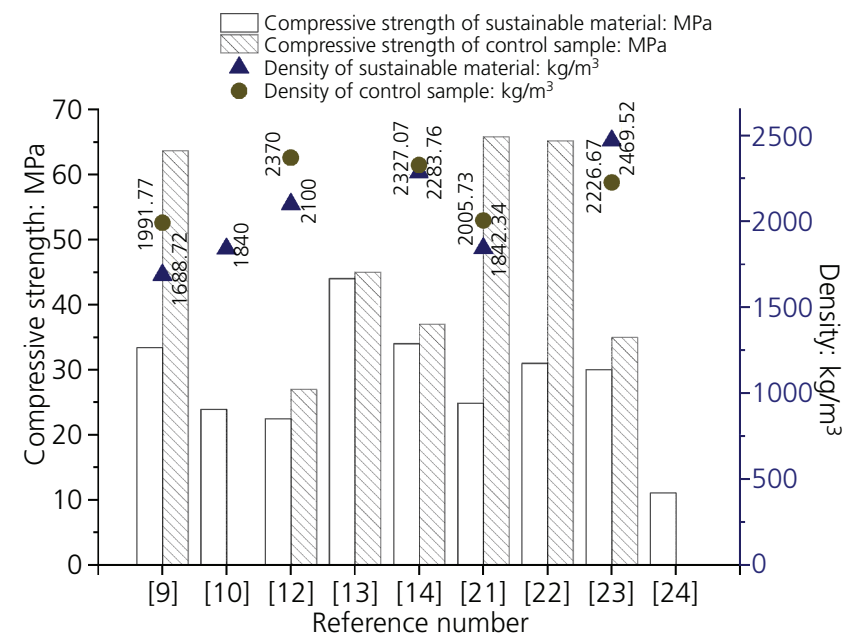

Figure 3. Compressive strength and density of cement-sludge mortar observed. ${ }^{13}$ SEM images have also confirmed the heterogeneity of the microstructure of the mortar leading to a reduction in strength $^{12}$ (Table 2). The presence of zinc and lead in textile sludge also affects the strength of a specimen, as it affects the hydration reactions that are responsible for the development of strength; hence, lower strength is observed. ${ }^{9}$ Moreover, a high volatile content in textile sludge is decomposed after a definite compressive strength is achieved. ${ }^{12}$ However, considering the requirement of the strength of construction materials, blocks produced using textile sludge accomplish the requirements of non-structural works as specified by the Bureau of Indian Standards (BIS). ${ }^{9,14,21,22}$

When it comes to the block density of specimens, blocks cast with $100 \%$ cement - that is, without sludge - showed a maximum density (Figure 3). ${ }^{14}$ With the increase in the percentage substitution of textile sludge in the mixes, the density started reducing. ${ }^{10,21}$ The lower density may be due to the lower specific weight of sludge compared with that of cement. ${ }^{10}$ The bulk density of specimens is also observed to increase up to an optimal amount of replacement by textile sludge, after which it starts to decrease. ${ }^{23}$ Hence, optimum usage of textile sludge is suggested by many researchers.

It can be seen from Figure 4 that the water absorption value of sustainable material is lower than that of the control sample. Thus, improvement in the value of water absorption is observed, ${ }^{23}$ as sludge appears to fill the voids of the mixtures. A maximum reduction of $71 \%$ is observed. It is also observed that after utilizing the optimum quantity of TETP sludge, the value of water absorption increases; hence, optimum utilization of textile sludge is suggested. ${ }^{13}$ It is seen that with the inclusion of textile sludge above $5 \%$ level in mortars, the value of water absorption increases. ${ }^{13}$ The increased replacement of sludge in mortar lowers

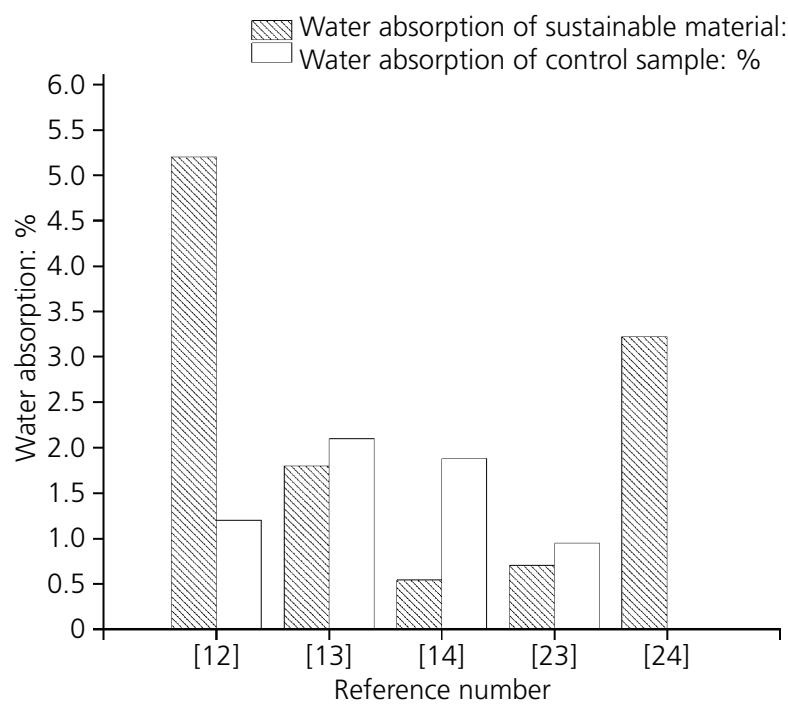

Figure 4. Water absorption of cement-sludge mortar 
the hydration reaction and results in inadequate pozzolanic action, thus affecting the water absorption value; hence, an optimum level of $5 \%$ is suggested. ${ }^{13}$ A variation in the results was seen due to the variation in the mix design carried out by the researchers. Mix design plays an important role in achieving the desired properties of sustainable materials. Thus, it can be concluded that with the proper utilization of TETP sludge and mix design, a new sustainable mortar can be developed with enhanced properties.

The toxicity characteristic leaching procedure of cement-sludge blocks was investigated in past studies to obtain the concentration of heavy metals in the leachate of the developed product, and the results showed negligible leaching of heavy metals. ${ }^{9,12,21}$ The heavy metal concentrations in the leachate were below threshold limits when compared with the regulatory limits of the US Environmental Protection Agency (EPA) and Department of Environment in Bangladesh.

\subsection{Application of TETP sludge to develop sustainable concrete}

From Figure 5, it is observed that the compressive strength of the concrete decreases with the increase in the percentage of textile sludge when used as a partial replacement for cement or aggregate. ${ }^{12,23-32}$ A maximum reduction of $50 \%$ is observed when compared with the test samples. A reduction in strength is observed because the sludge is finer than cement particles, and its hydroscopic nature causes it to increase in volume, ${ }^{33}$ thus, during mixing, demand for water increases to maintain workability, ${ }^{27}$ hence affecting the water-cement ratio. The presence of chlorides and sulfates in textile sludge also diminishes the quality of concrete. ${ }^{24}$ Although the strength of concrete is decreased, the obtained strength fulfills the requirements of many non-structural materials ${ }^{12}$ or components as specified in many standards - namely, ASTM and Indian standards. Therefore, many researchers have suggested the optimal quantity of textile sludge that can be used in concrete (Figure 5). An increase in the strength of concrete due to partial replacement with textile sludge has also been reported in some research studies. ${ }^{34,35}$ A maximum percentage increase of $11 \%$ is observed compared with the control sample, which may be due to the presence of some percentage of silica and calcium content in TETP. The use of TETP-compatible superplasticizers in concrete mix also enhances the compressive strength of concrete. ${ }^{36}$ A concrete mix design parameter such as water content in combination of TETP and cement may be the cause of this increased strength. As mix design involves mixing of various ingredients in suitable proportions in which each ingredient has unique properties and these properties vary from source to source, the proportion of each ingredient affects the strength of the developed concrete. Besides, the suitability of the admixture used in the mix also improves the properties of concrete. Thus, by looking at the results, it may be inferred that with the appropriate mix design, there is a possibility to develop sustainable concrete with enhanced properties (Figures 6 and 7). A similar trend is observed for the split tensile strength and flexural strength of textile-sludge-incorporated concrete. The increase in strength may be due to the cohesive nature of textile sludge. ${ }^{23}$ A maximum increase of $6 \%$ and a decrease of $28 \%$ are observed in split tensile strength compared with the control sample. Similarly, a 15\% increase in flexural strength and a reduction of $16 \%$ are observed. Water absorption and quantity of sludge added are directly proportional with each other. ${ }^{37,38}$ The porosity of the specimen increases with an increase in the content of textile sludge in the concrete; subsequently, density is reduced and water absorption capacity increases (Figure 5). A maximum increase of $21 \%$ and a reduction of $40 \%$ in water absorption capacity are observed compared with the test samples. The toxicity characteristic leaching procedure was performed by past researchers using fractured particles of sludge-incorporated concrete blocks as per the US EPA method, the Japan Society of Civil Engineers standard leaching test method and so on. ${ }^{12,26}$ It was found that none of the samples exceeded the

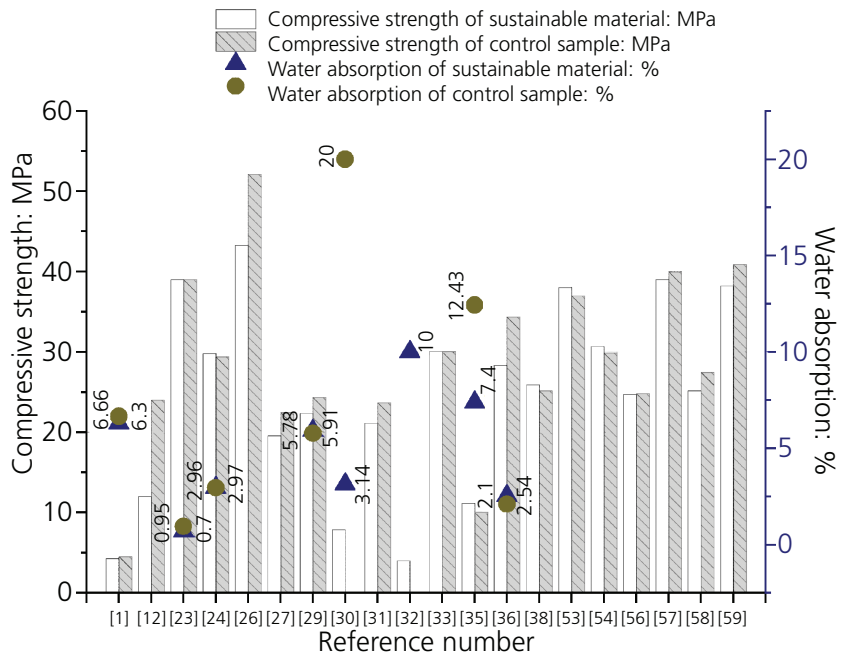

Figure 5. Compressive strength and water absorption of concrete blocks or bricks

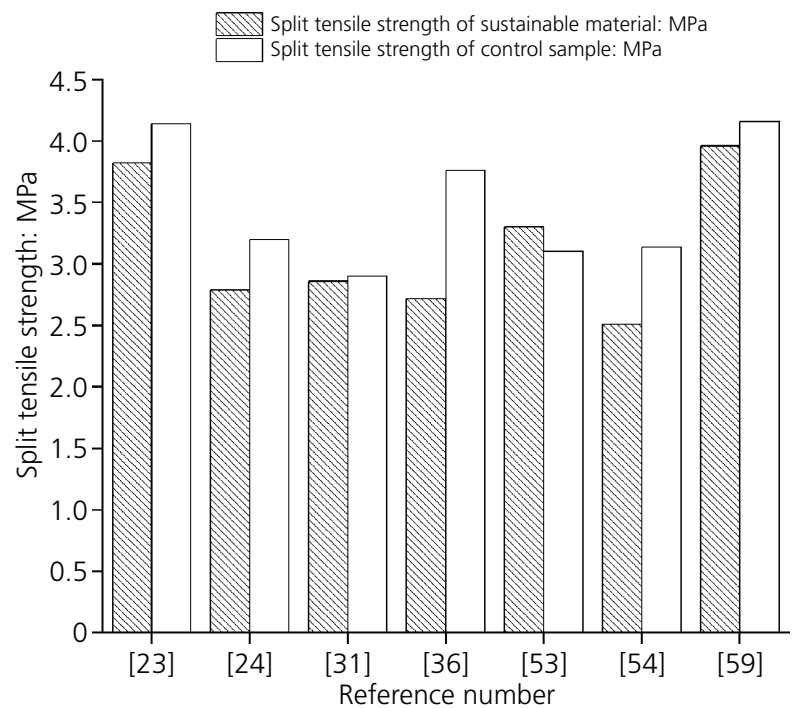

Figure 6. Split tensile strength of concrete blocks or bricks 


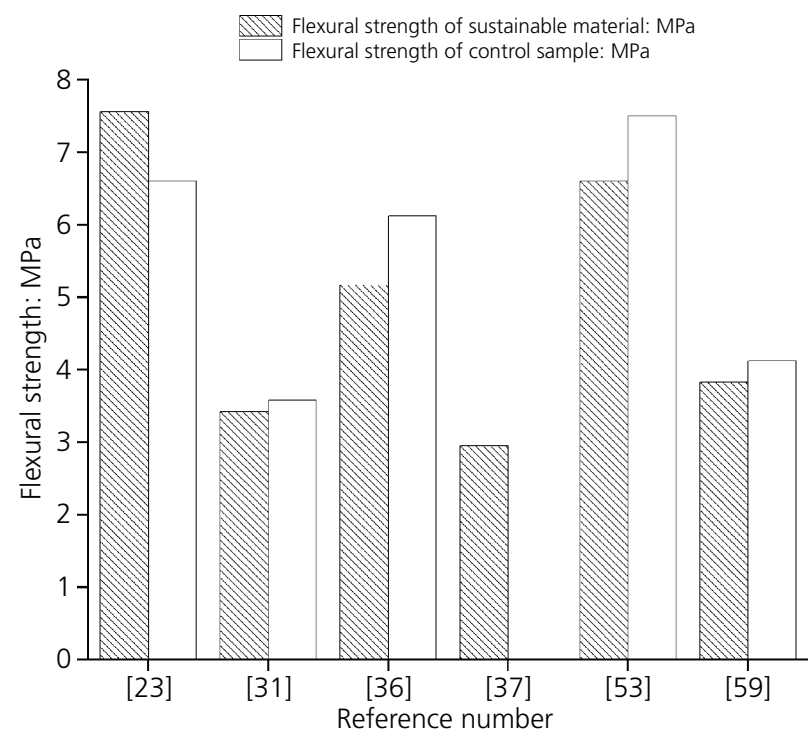

Figure 7. Flexural strength of concrete blocks or bricks

threshold values, as given by the US EPA and the Department of Environment in Bangladesh.

\subsection{Utilization of TETP sludge to develop sustainable clay bricks}

From Figure 8, it is seen that the compressive strength of textilesludge-incorporated clay bricks decreases with the percentage increase in the composition of the textile sludge when partially replaced with soil. ${ }^{1,6,11,15,17-19,39}$ A maximum percentage decrease of $35 \%$ is observed when compared with control bricks. The chemical characterization of textile sludge shows the presence of organic matter; this volatile organic matter is volatilized during the burning process, hence resulting in a volumetric increase in pores. ${ }^{6,17,18}$ This causes porosity in the bricks, and the percentage of weight loss increases in textile sludge bricks (Figure 9). A maximum weight loss of $83 \%$ is observed, due to which the strength of bricks reduces. ${ }^{11}$ In some of the other studies, it is also observed that bricks developed with textile sludge exhibited higher compressive strength compared with control bricks ${ }^{40-42}$ and the maximum increase in percentage is $90 \%$ (Figure 8). A gradual increment in strength was observed at an optimum quantity of sludge and then decreased after reaching that quantity. Hence, optimum utilization of sludge in bricks is suggested for the production of good bricks. It has been found that an optimum quantity of TETP sludge in the bricks has satisfied the norms of first-class bricks of the Indian standards, ${ }^{6}$ class III brick strength of $3.5 \mathrm{~N} / \mathrm{mm}^{2}$ or more ${ }^{17}$ of IS standards ${ }^{11}$ and ASTM standards. ${ }^{42}$

The density of bricks/blocks is affected and is found to reduce with a percentage increase in the quantity of textile sludge (Figure 10). ${ }^{6,11,17,18}$ A maximum decrease of $14 \%$ in density is observed.

Water absorption is directly proportional to the quantity of textile sludge added to the compositions. ${ }^{19}$ A maximum increase in water absorption capacity of $80 \%$ is found when compared with the test sample (Figure 8). A higher amount of void spaces in the microstructure of textile-sludge-incorporated bricks subsequently increases the consumption of water; thus, the water absorption capacity increases. ${ }^{6,11,16,18,42-44}$ The water absorption capacity of green bricks is lower than that of burnt clay bricks. ${ }^{42}$ The addition of glass in combination with sludge could result in reducing the water absorption capacity of bricks by clogging their voids ${ }^{41}$ (Figure 9). It is also observed that the firing temperature and its corresponding duration play a vital role in the development of strength. Strength increases with the increase in firing temperature and firing duration ${ }^{11,18,19}$ (Figure 11). Shrinkage of the sludgeincorporated clay bricks is found to increase with the increase in sludge content.

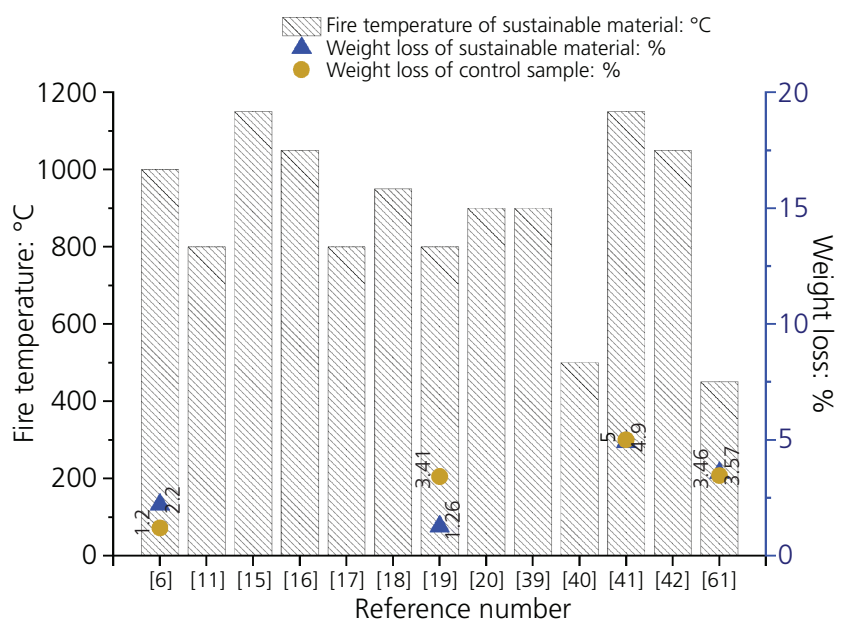

Figure 9. Firing temperature and weight loss of clay bricks

Figure 8. Compressive strength and water absorption of clay bricks 


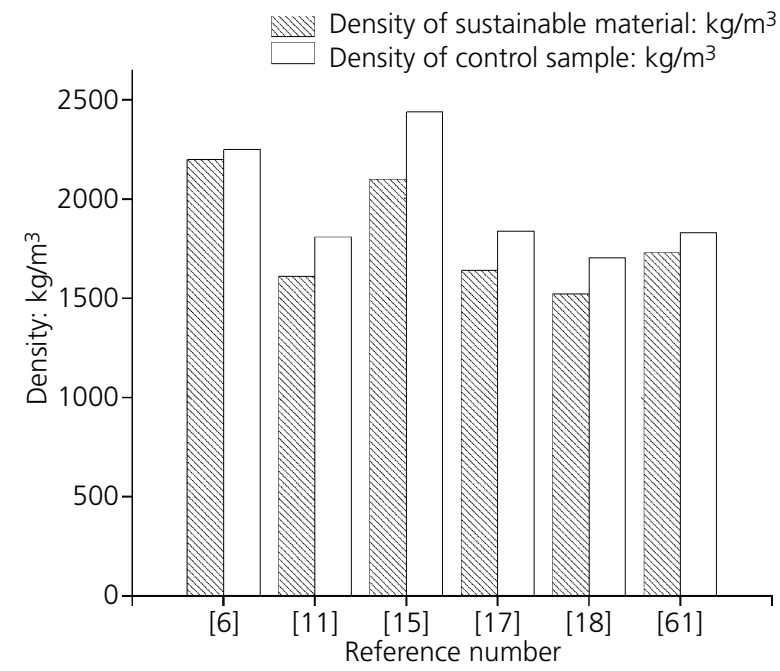

Figure 10. Density of clay bricks

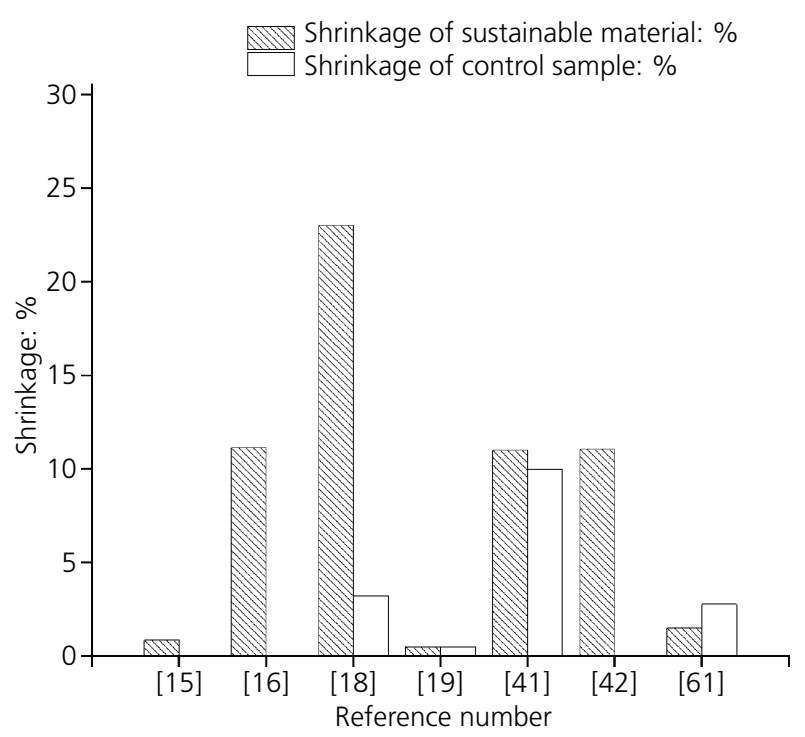

Figure 11. Shrinkage of clay bricks

Toxicity characteristic leaching procedure tests performed on sludgeincorporated bricks indicated that most heavy metals were not detectable in the leachates of the brick product, ${ }^{15,16,42}$ and the levels of the few detectable heavy metals were found to satisfy the standard regulations - namely, Dutch regulations. The reduction in heavy metal concentrations in the developed product may be due to dilution of the concentration of heavy metals present in the raw material during the blending process and due to evaporation of heavy metals present in the brick product during the firing process.

\subsection{Development of paver blocks using TETP sludge}

The maximum compressive strength of paver blocks was found to decrease with an increase in the percentage substitution of textile sludge with cement (Figure 12). ${ }^{45-48}$ A maximum reduction of $11 \%$ is observed compared with test blocks. IS 15658:2006 recommends a minimum strength of $30 \mathrm{MPa}$ for paver blocks in building premises and public gardens/parks ${ }^{48}$ (Figure 12). It can be seen that the maximum compressive strength reported by many past researchers was above $30 \mathrm{MPa}$, which fulfills the requirement of BIS.

As far as flexural strength is concerned, it decreases with the increase in the amount of sludge added as a partial replacement of cement (Figure 13). ${ }^{45,46}$

Loss of thickness was observed in sludge-incorporated blocks when sludge was used as a partial replacement of cement. ${ }^{46}$

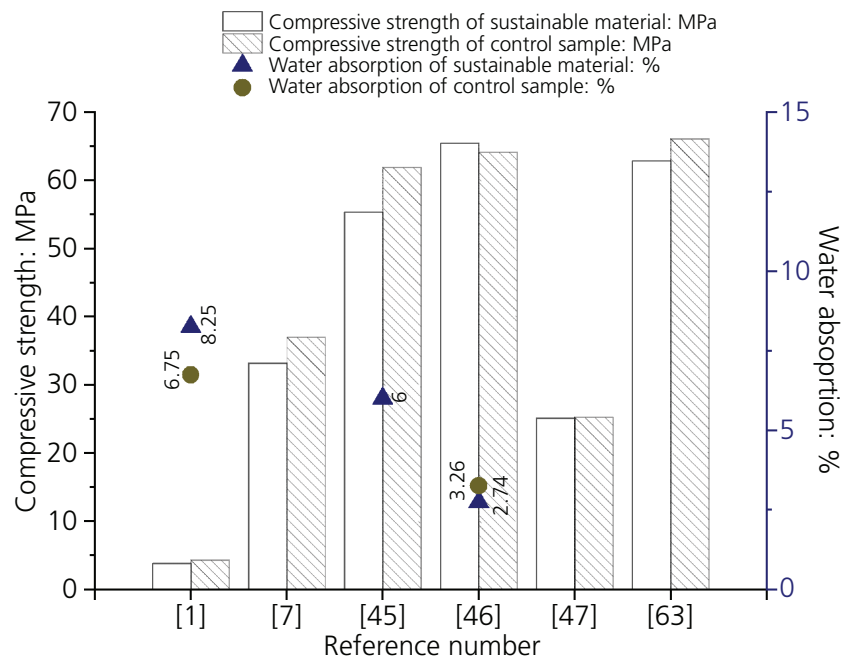

Figure 12. Compressive strength and water absorption of paver blocks

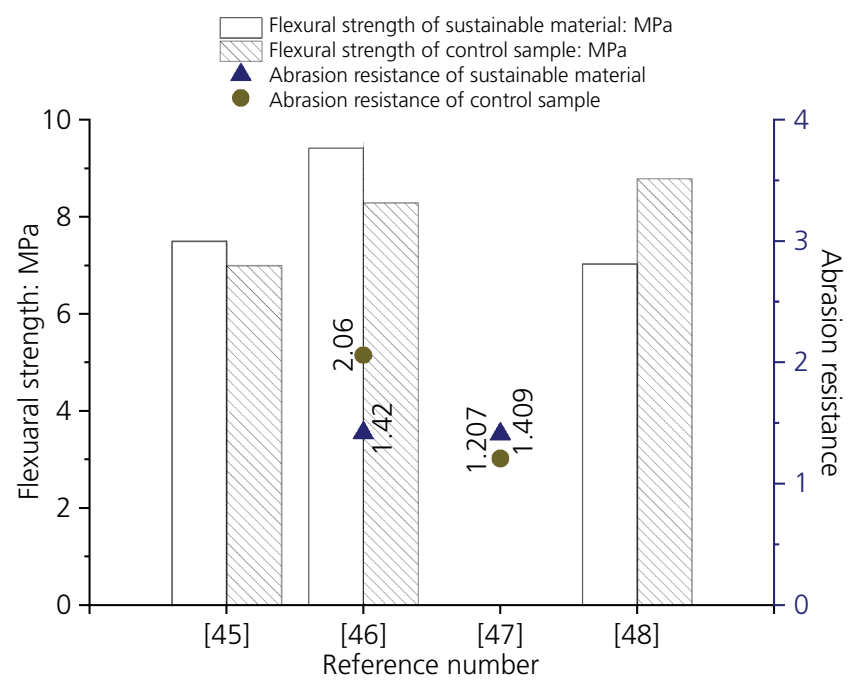

Figure 13. Flexural strength and abrasion resistance of paver blocks 
The losses observed were within 2-2.5 mm, which satisfies the recommendations of IS 1237:1980. ${ }^{68}$

The water absorption of each block tested is less than $10 \%$, which fulfills BIS requirements. ${ }^{1}$

\section{Discussion}

An abundant quantity of around $70-80 \mathrm{Mt}$ of TETP sludge is generated per day in India, ${ }^{7,8}$ which is disposed of in landfills, subsequently causing environmental pollution. Thus, extensive literature studies were performed pertaining to the development of sustainable construction materials. Table 1 shows the various types of equipment utilized by various researchers for the chemical characterization of TETP sludge and the developed sustainable products. It is seen that the composition of sludge varies from place to place and depends on the type of treatment process involved. Enormous variations in the chemical composition of sludge were observed. Sludge waste has silicon dioxide in a larger amount, which shows its siliceous nature. The presence of a high calcium and magnesium content indicates its potential as a partial replacement for the manufacturing of sustainable construction material. The presence of metals such as aluminum ( $\mathrm{Al}$ ), iron and calcium is indicative of the oxide composition of base-clay materials. Heavy metals such as cadmium and chromium were found to be within regulatory limits. Thus, sludge can be used directly as a raw material without creating any negative impact on the environment. The present paper reviewed that various researchers have substituted TETP sludge in various optimum proportions ranging from 0 to $50 \%$ and adopted various methodologies for the development of sustainable concrete, bricks, mortars and paver blocks (Figure 2). The common parameter tests that were performed by researchers were compressive strength, water absorption and density tests, for investigating the properties of the developed product (Tables 3-6). It is discovered that the concrete produced by using TETP sludge showed appreciable strength up to a certain limit, but after reaching the optimum limit of replacement, the strength started reducing. A similar trend was observed for other developed sustainable products such as mortar, bricks and paver blocks with various other mechanical tests. The maximum compressive strength was observed in the control samples. It was observed that the compressive strength of block with an optimum quantity of sludge $^{1}$ satisfied the minimum required strength of $4 \mathrm{~N} / \mathrm{mm}^{2}$ for grade D, load-bearing units of IS 2185(Part 1):1979. ${ }^{49}$ Also, blocks developed with sludge satisfied ASTM C 129-75 standards for non-load-bearing concrete masonry units. ${ }^{50}$ Clay bricks developed with the optimum quantity of sludge were found to have compressive strength greater than $3.5 \mathrm{~N} / \mathrm{mm}^{2}$ as specified in IS 1077:1979 for bricks in load-bearing units. ${ }^{51}$ The value of water absorption of blocks developed by many researchers was less than $10 \%$, which meets the requirements of BIS. ${ }^{49}$ The water absorption value of bricks was found to be less than $20 \%$, as prescribed in IS; for paver blocks, water absorption values were less than $10 \%$, which meet the requirements of BIS. ${ }^{52}$ As far as block density is concerned, the blocks achieved

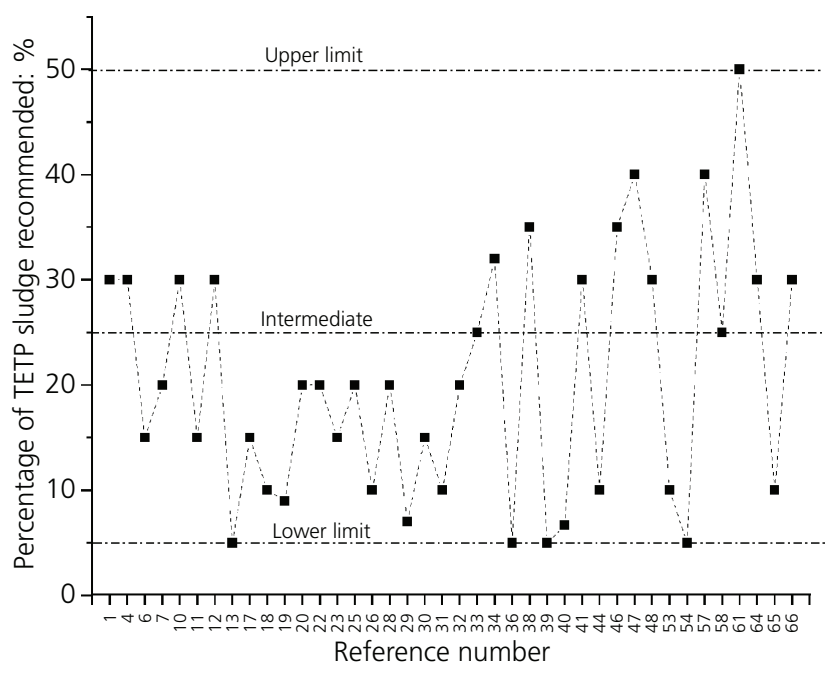

Figure 14. Percentage substitution of TETP sludge recommended by various researchers ${ }^{69}$

a density greater than $1800 \mathrm{~kg} / \mathrm{m}^{3}{ }^{49}$ As per ASTM C $129-75$ standards, the developed blocks were categorized as normal weight. $^{50}$ Researchers have suggested utilizing an optimum quantity of sludge to achieve desirable properties in sustainable material. Optimum replacement percentages ranged from 5 to $30 \%$ for mortar, from 5 to $40 \%$ for concrete, from 5 to $50 \%$ for clay bricks and from 20 to $40 \%$ for paver blocks (Figure 14). This indistinctness in the optimum replacement percentage is due to the variations (Table 2) in the chemical composition of sludge and variation in the type of product. When looking at the performance of the developed sustainable construction material, it can be said that with the proper mix design, TETP sludge has the potential to be used in creating structural or non-structural building components that will help meet the increasing demand for construction material. Also, with the optimum usage of TETP sludge ranging from intermediate to higher limits (Figure 14), production of cement can be minimized; thus, reduction in the consumption of natural resources can be achieved. Consequently, carbon dioxide footprints will be substantially reduced.

\section{Conclusion}

The various methodologies pertaining to the development of sustainable construction materials such as mortar, concrete, clay bricks and paver blocks have been extensively reviewed. Various microscopic examinations and physicochemical and mechanical tests involved in the development of TETP-sludge-incorporated sustainable material have been studied in accordance with the reviewed literature and standards. From this review study, the following conclusions have been drawn.

- The chemical composition of TETP sludge shows its potential to be used in developing sustainable construction materials. 
- Usage of TETP sludge as an alternative raw material to cement, fine aggregate and clay in the construction industry is feasible without compromising the quality and strength as prescribed by many standards - namely, IS 2185(Part 1):1979, IS 1077:1979 and ASTM C 129-75.

- The optimum ranges for the development of mortar, concrete, clay bricks and paver blocks are 5-30, 5-40, 5-50 and 20-40\%, respectively.

- When looking at the replacement percentages, it can be concluded that a maximum of up to $40 \%$ TETP sludge with proper mix design can be used as a substitute with or without additives for the manufacturing of structural or non-structural building components, which would provide a cost-effective solution to fulfill the demand for construction materials and also provide an alternative solution to the problems arising due to direct disposal of TETP sludge on land.

- Many researchers have utilized TETP sludge as a partial replacement for cement, fine aggregates and clay for the development of sustainable construction material. However, the thermal and functional performance of TETP-sludgeincorporated small-scale models under real-life conditions was not commonly observed in past studies.

- The techno-economic feasibility of the developed product can be explored using cost-benefit analysis for its commercial applications.

- Thermal and energy building simulation along with life-cycle assessment are the prominent areas for further research.

- Fatigue life assessment of developed paver block might prove an important aspect of the design of TETP-sludgeincorporated pavements.

\section{REFERENCES}

1. Balasubramanian J, Sabumon PC, Lazar JU and Ilangovan R (2006) Reuse of textile effluent treatment plant sludge in building materials. Waste Management 26(1): 22-28.

2. Development Alternatives (1997) The construction sector in India and climate change. Development Alternatives Newsletter, January. See https://www.devalt.org/Newsletter/Jan97/of 1.Htm (accessed 17/ 06/2021).

3. Ministry of Housing and Urban Poverty Alleviation (2011) Report of the Technical Group (TG-12) on the Urban Housing Shortage. National Buildings Organisation, New Delhi, India

4. MORD (Ministry of Rural Development) (2011) Working Group on Rural Housing for the 12th Five Year Plan. MORD, New Delhi, India.

5. Ministry of Textiles (2020) 2019-2020 Annual Report. Government of India, New Delhi, India.

6. Begum BSS, Gandhimathi R, Ramesh ST and Nidheesh PV (2013) Utilization of textile effluent wastewater treatment plant sludge as brick material. Journal of Material Cycles and Waste Management 15(4): 564-570.

7. Patel K, Patel RL and Pitroda J (2017) Technical feasibility study on utilization of textile sludge as a cement substitute in rubber mould paver block. International Journal of Constructive Research in Civil Engineering 3(1): 19-25.

8. Pattnaik P, Dangayach GS and Bhardwaj AK (2018) A review on the sustainability of textile industries wastewater with and without treatment methodologies. Reviews on Environmental Health 33(2): 163-203.
9. Patel H and Pandey S (2012) Evaluation of physical stability and leachability of Portland Pozzolona Cement (PPC) solidified chemical sludge generated from textile wastewater treatment plants. Journal of Hazardous Materials 207-208: 56-64.

10. Jahagirdar SS, Shrihari S and Manu B (2012) Reuse of textile mill sludge in cement based solid blocks. International Journal of Engineering Research and Industrial Applications 5(III): 213-224.

11. Jahagirdar SS, Shrihari S and Manu B (2013) Utilization of textile mill sludge in burnt clay bricks. International Journal of Environmental Protection 3(5): 6-13.

12. Rahman MM, Khan MMR, Uddin MT and Islam MA (2017) Textile effluent treatment plant sludge: characterization and utilization in building materials. Arabian Journal for Science and Engineering 42(4): 1435-1442

13. Goyal S, Siddique R, Jha S and Sharma D (2019) Utilization of textile sludge in cement mortar and paste. Construction and Building Materials 214: 169-177.

14. Vellingiri S, Velumani P and Senthilkumar S (2015) An experimental approach to evaluate the performance for the reuse of textile industry sludge. International Journal of Applied Engineering Research 10(38): 28172-28175.

15. Chen C and Wu H (2018) Lightweight bricks manufactured from ground soil, textile sludge, and coal ash. Environmental Technology 39(11): 1359-1367.

16. Anwar TB, Behrose B and Ahmed S (2018) Utilization of textile sludge and public health risk assessment in Bangladesh. Sustainable Environment Research 28(5): 228-233.

17. Jahagirdar SS, Shrihari S and Manu B (2013) Reuse of textile mill sludge in burnt clay bricks. International Journal of Advanced Technology in Civil Engineering 2(1): 96-99.

18. Jewaratnam J and Samat NFNA (2020) Potential recovery of a textile wastewater treatment plant sludge into clay bricks. Research Communication in Engineering Science \& Technology 4: 15-23.

19. Baskar R, Begum K and Sundaram S (2006) Characterization and reuse of textile effluent treatment plant waste sludge in clay bricks. Journal of the University of Chemical Technology and Metallurgy 41(4): 473-478.

20. Herek LCS, Hori CE, Reis MHM et al. (2012) Characterization of ceramic bricks incorporated with textile laundry sludge. Ceramics International 38(2): 951-959.

21. Patel $\mathrm{H}$ and Pandey S (2009) Exploring the reuse potential of chemical sludge from textile wastewater treatment plants in India - a hazardous waste. American Journal of Environmental Sciences 5(1): 106-110.

22. Jeevanandam S, Ravikumar K, Das A and Goel M (2015) Comprehensive study on textile dyeing sludge as a substitute for cement in cement-mortar. International Journal of Technology 5(2): 219.

23. Arul N, SenthilKumar S and Velumani P (2017) Studies on behaviour of concrete with ETP sludge. International Journal of Applied Engineering Research 10(38): 28182-28185.

24. Raghunathan T, Gopalsamy P and Elangovan R (2010) Study on strength of concrete with ETP sludge from dyeing industry. International Journal of Civil and Structural Engineering 1(3): 379-389.

25. Palanisamy $V$ (2011) Utilization of textile effluent waste sludge in brick production. International Journal of Sciences: Basic and Applied Research 4(1): 1-10.

26. Zhan BJ and Poon CS (2015) Study on feasibility of reutilizing textile effluent sludge for producing concrete blocks. Journal of Cleaner Production 101: 174-179.

27. Loganayagan S, Rajkumar G, Pavthra A and Poonkundran M (2020) Experimental study on concrete by partial replacement of fine aggregate by textile effluent treatment plant sludge. IOP Conference Series: Materials Science and Engineering 764(1): article 012043. 
28. Praveen S, Bhagavathi TP, Jegan J et al. (2015) Utilization of textile effluent waste sludge in brick. International Journal of Sciences. Basic and Applied Research 2(12): 3103-3107.

29. Altidis MED, Morais CRS, Rodrigues PA, Pereira LMS and Guedes BFR (2014) Study of mechanical properties and development of concrete using sludge from textile industry. Materials Science Forum 798-799: 554-557.

30. Velumani P, Senthil Kumar S and Premalatha PV (2016) An innovative approach to evaluate the performance of sludgeincorporated fly ash bricks. Journal of Testing and Evaluation 44(6): 2155-2163.

31. Anandh S, Sindhu N S and Jagannatan S (2018) Study on impact of partial replacement of cement by textile sludge and GGBS in concrete. International Journal of Pure and Applied Mathematics 119(7): 1195-1201.

32. Krishnan SM and Giridev VR (2010) Utilization of Textile Effluent Waste Sludge in Brick Production. Fibre2Fashion Pvt. Ltd, Ahmedabad, India. See https://www.fibre2fashion.com/industryarticle/4916/utilization-of-textile-effluent-waste-sludge-in-brickproduction (accessed 05/07/2021).

33. Kaur H, Singh J and Khattra SK (2019) Utilization of textile mill sludge waste in concrete - an experimental study. Indian Journal of Pure \& Applied Biosciences 7(5): 179-185.

34. Kulkarni GJ, Dwivedi AK and Jahgirdar SS (2012) Textile mill sludge as fine aggregate in concrete. Global Journal of Researches in Engineering Industrial Engineering 12(2): 203-214.

35. Gunavel M and Shahathiya ML (2019) Experimental study on strength of brick using ETP sludge and cement. International Journal of Engineering Research \& Technology 8(2): 164-166.

36. Sandesh NU, Varun K and Prashanth VP (2014) A study on engineering properties of textile ETP sludge based cement concrete. International Journal of Innovations in Engineering and Technology 4(4): 324-330.

37. Binici $H$, Gemci $R$, Aksogan $O$ and Kaplan $H$ (2010) Insulation properties of bricks made with cotton and textile ash wastes. International Journal of Materials Research 101(7): 894-899.

38. Kaur H, Singh J and Khattra SK (2017) The workability and compressive strength of concrete using textile mill sludge and plasticizer. International Journal of Civil, Structural, Environmental and Infrastructure Engineering Research and Development 7(4): 1-8.

39. Priyadharshini B and Kavisri M (2018) Utilization of textile sludge in manufacturing e-bricks. International Journal of Civil Engineering and Technology 9(11): 2266-2273.

40. Mary LPN and Sreeja MS (2014) Utilization of sludge in manufacturing Energy Efficient Bricks. IOSR Journal of Mechanical and Civil Engineering 11(4): 70-73.

41. Rahman A, Urabe T, Kishimoto N and Mizuhara S (2015) Effects of waste glass additions on quality of textile sludge-based bricks. Environmental Technology 36(19): 2443-2450.

42. Anwar TB, Behrose B and Ahmed S (2017) Characterization and utilization of textile sludge for environment-friendly applications. Proceedings of the Fifth International Conference on Chemical Engineering (ICChE 2017), Dhaka, Bangladesh, pp. 274-280.

43. Patel $\mathrm{H}$ and Pandey S (2008) Physico-chemical characterisation of textile chemical sludge generated from various CETPs in India. Journal of Environmental Research and Development 2(3): 329-339.

44. Ravikrishnan S and Senthilselvan S (2014) Novel Green Bricks manufactured from Textile ETP Sludge. International Journal of Scientific and Engineering Research 5(6): 76-81.

45. Narayan BA and Supriya J (2017) A study on textile sludge management. International Journal of Research in Engineering and Applied Sciences 2(5): 299-306.

46. Velumani P and Senthilkumar S (2018) Production of sludgeincorporated paver blocks for efficient waste management. Journal of the Air \& Waste Management Association 68(6): 626-636.
47. Indumathi M, Mohana BL, Revath PA and Saravanan V (2017) Experimental investigation on partial replacement of ETP sludge from textile industry on paver block. International Journal for Scientific Research and Development 5(2): 1178-1181.

48. Kishore V (2012) Utilization of sludge concrete in paver blocks. International Journal of Emerging Trends in Engineering and Development 4(2): 509-516.

49. BIS (Bureau of Indian Standards) (1979) IS 2185(Part 1):1979: Specification for concrete masonry units - hollow and solid concrete blocks. BIS, New Delhi, India.

50. ASTM (1975) C 129-75: Standard specification for non-load-bearing concrete masonry units. ASTM International, West Conshohocken, PA, USA.

51. BIS (1979) IS 1077:1979: Specification for common burnt clay building bricks. BIS, New Delhi, India.

52. BIS (2006) IS 15658:2006: Specification for precast concrete blocks for paving. BIS, New Delhi, India.

53. Mariappan C, Natarajan M and Sathanandham T (2018) Utilization of flyash and ETP sludge in concrete with addition of banana fiber. International Journal of Civil Engineering and Technology 9(1): 398-406.

54. Joseph P and Kumar CS (2017) Comparative study on effects of quartz powder and textile sludge on strength of concrete. International Journal of Engineering Trends and Technology 47(1): 60-65.

55. Lekshmi S and Sasidharan S (2015) Experimental investigation on the use of textile sludge in concrete. International Journal of Advances in Engineering and Technology 8(4): 559-565.

56. Pradeepa S, Anitha J, Kumar HR, Pranav P and Jaketia A (2015) An experimental investigation on low cost concrete. Proceedings of the 2015 National Conference on Recent Trends in Cement Concrete Composites for Structural Systems, Manalmedu, India, pp. 417-419.

57. Prabhu RS, Ahilsaravanan VJ, Aravindh M, Naveenkumar S and Sarankumar S (2019) Experimental study on sludge from common effluent treatment plant as a partial replacement of fine aggregate in concrete. International Journal of Scientific and Engineering Research 10(3): 218-223.

58. Kaur H and Singh J (2019) Compressive strength of concrete by partial replacement of cement with textile mill sludge. International Journal of Recent Scientific Research 10(7): 33384-33387.

59. Sakthivel S, Sarathi M, Sathish S and Sivakumar M (2019) Experimental investigation on textile mill sludge with partial replacement of fine aggregate in concrete. International Research Journal of Engineering and Technology 6(3): 7404-7407.

60. Rahman MT and Khandaker N (2017) Physical properties of dewatered waste sludge from textile processing wastewater facility for construction material application. In Renewable Energy and Its Innovative Technologies (Chattopadhyay J, Singh R and Prakash O (eds)). Springer, Singapore, pp. 25-30.

61. Hossain MS, Das SC, Mamun MAA et al. (2016) Fabrication and mechanical characterization of gamma irradiated textile sludge bricks. Proceedings of the 2016 International Conference on Mechanical, Industrial and Energy Engineering, Khulna, Bangladesh.

62. Jayakumar PT, Ram Kumar VR, Suresh BR and Kumar M (2013) Experimental investigation on paver blocks using steel slag as partial replacement of aggregate and sludge as partial replacement of cement. International Journal of Science and Research 2(5): 87-91.

63. Sudheesh C, Kumar TRP and Kumar S (2015) Effect of compressive strength on concrete by partial replacement of cement with textile sludge and polypropylene fibers. International Journal of ChemTech Research 8(4): 2219-2226.

64. Cheriaf M, Rocha JC and Pera J (2000) Solidification/stabilization of textile sludge with Portland cement and bottom ash. In Sustainable Construction: Use of Incinerator Ash (Dhir RK, Dyer TD and Paine KA (eds)). Thomas Telford, London, UK, pp. 381-391. 
65. Iqbal SA, Mahmud I and Quader AKMA (2014) Textile sludge management by incineration technique. Procedia Engineering 90: 686-691.

66. Zhang R, Ren HQ, Ding LL et al. (2015) Evaluating solidification characteristics of textile dyeing sludge with addition of Portland cement and attapulgite. Applied Mechanics and Materials 768: 375-384.

67. Velumani P and Gokulnath C (2019) Development of terrace flooring tiles using fly ash and textile industry sludge. International Journal of Engineering Sciences \& Research Technology 8(4): 187-192.
68. Sathanandham T, Kumar S, Vijayan V and Ashokkumar D (2019) Flexural behaviour on beam in sludge-cement replacement concrete. Journal of Sustainable Construction Engineering and Project Management 2(2): 1-7.

69. Sathanandham T, Haripriya S, Prabhanjan N, Sahithi G and Swamy G (2020) Assessment of the polypropylene fiber reinforced concrete with wastewater lime sludge. International Journal of Innovative Technology and Exploring Engineering 9(4): 2827-2830

\section{How can you contribute?}

To discuss this paper, please submit up to 500 words to the journal office at journals@ice.org.uk. Your contribution will be forwarded to the author(s) for a reply and, if considered appropriate by the editor-in-chief, it will be published as a discussion in a future issue of the journal.

ICE Science journals rely entirely on contributions from the field of materials science and engineering. Information about how to submit your paper online is available at www.icevirtuallibrary.com/page/authors, where you will also find detailed author guidelines. 